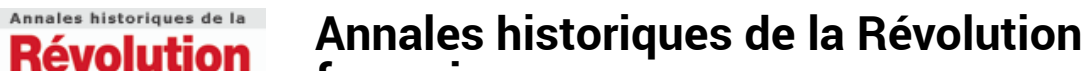 \\ française française
}

326 | octobre- décembre 2001

La Révolution Batave. péripéties d'une République-

Soeur (1795-1813)

Jean-Marie WISCART, Grands notables du Premier Empire, Somme, Paris, CNRS Éditions, 2000, 110 p. Jacques Bernet

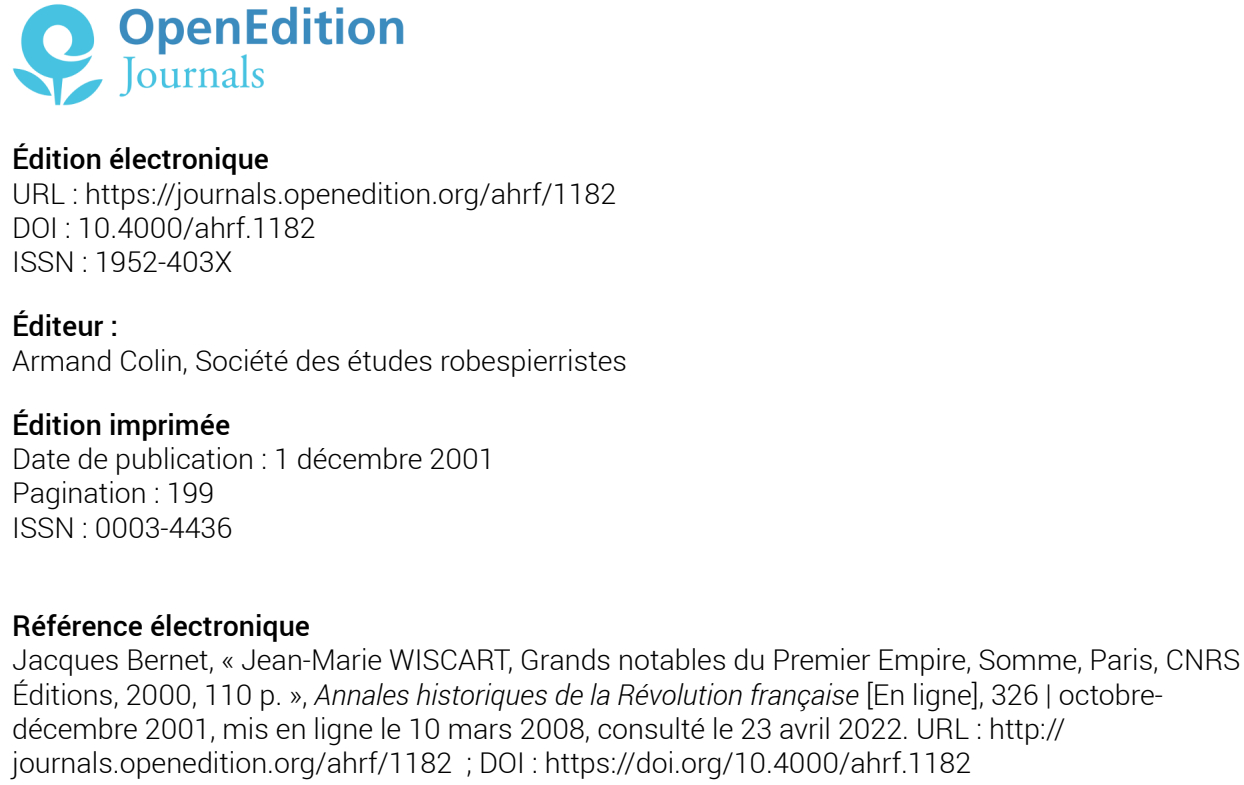

Édition électronique

URL : https://journals.openedition.org/ahrf/1182

DOI : $10.4000 /$ ahrf. 1182

ISSN : 1952-403X

Éditeur :

Armand Colin, Société des études robespierristes

Édition imprimée

Date de publication : 1 décembre 2001

Pagination : 199

ISSN : 0003-4436

Référence électronique

Jacques Bernet, « Jean-Marie WISCART, Grands notables du Premier Empire, Somme, Paris, CNRS

Éditions, 2000, 110 p. », Annales historiques de la Révolution française [En ligne], 326 | octobre-

décembre 2001, mis en ligne le 10 mars 2008, consulté le 23 avril 2022. URL : http://

journals.openedition.org/ahrf/1182 ; DOI : https://doi.org/10.4000/ahrf.1182

Ce document a été généré automatiquement le 23 avril 2022.

Tous droits réservés 


\title{
Jean-Marie WISCART, Grands notables du Premier Empire, Somme, Paris, CNRS Éditions, 2000, $110 \mathrm{p}$.
}

\author{
Jacques Bernet
}

Jean-Marie Wiscart, maître de conférences en histoire contemporaine à l'Université de Picardie-Jules Verne, dont la thèse a été consacrée à la noblesse de la Somme au XIX ${ }^{\mathrm{e}}$ siècle, était assurément bien placé pour réaliser cette monographie départementale, tome $27 \mathrm{du}$ vaste recensement national conduit depuis plusieurs décennies par Louis Bergeron et Guy Chaussinand-Nogaret. Le fascicule présente les biographies de 84 personnalités locales, correspondant aux 12 propriétaires les plus imposés de l'an X, aux 60 «plus distingués» de l'an XIII et aux 30 plus imposés en 1806. Respectant les normes scientifiques de l'entreprise, l'auteur fournit ses sources et «pistes bibliographiques ", tout en s'efforçant de caractériser dans l'introduction le profil social du corpus, établi par le préfet Quinette, de ces personnages « réputés fidèles au nouveau régime »: «Anciens privilégiés capables de s'intégrer au nouvel ordre de la France, fière oligarchie du négoce amiénois, manufacturiers du coton ouverts à l'esprit d'innovation, seigneurs en battes du Santerre ». Près de la moitié avaient appartenu à l'ancienne (petite) noblesse et cinq d'entre eux devaient être de surcroît anoblis sous l'Empire ou la Restauration. Propriétaires et rentiers dominaient, suivis de représentants des milieux d'affaires urbains, d'ailleurs plus négociants que manufacturiers, de quelques gros cultivateurs, cadres administratifs et militaires. Ces notables avaient généralement été des partisans modérés de la Révolution - Ils ont siégé dans les assemblées de la décennie révolutionnaire, mais le seul préfet Quinette avait été représentant de l'Aisne à la Convention. Un bon tiers ont acquis des biens nationaux. N'apparaît que la Somme, certes département d'adoption sinon d'action politique de Gracchus Babeuf, fut terre d'une «révolution tranquille» et l'on en a certainement là une des explications, si l'on y considère l'adaptation globalement aisée des anciennes élites au nouveau cours politique, assurant la pérennité de leur poids 
social et de leur influence politique. C'est là un des intérêts majeurs de ce type de recensement biographique pour les historiens de la Révolution française. 